\title{
Implementasi Bentuk Layanan Bimbingan dan Konseling Pada Anak Kelompok B1 Usia 5-6 Tk Islam Terpadu Permata Mandiri Billah 3 Banyuwangi Tahun Ajaran 2017/2018 (Implementation of Guidance and Counseling Services for Students Group B1 Age 5-6 TK Islam Terpadu Permata Mandiri Billah 3 Banyuwangi Academic Year 2017/2018)

\author{
Zulma Aimmatul, Nanik Yuliati, Khutobah \\ Jurusan Ilmu Pendidikan, Fakultas Keguruan dan Ilmu Pendidikan, Universitas Jember (UNEJ) \\ Jln. Kalimantan 37, Jember 68121 \\ E-mail :nanikyuliati@gmail.com
}

\begin{abstract}
Abstrak
Tujuan penelitian ini adalah untuk mendeskripsikan implementasi bentuk layanan bimbingan dan konseling pada anak kelompok B1 usia 5-6 TK Islam Terpadu Permata Mandiri Billah 3 Banyuwangi tahun ajaran 2017/2018. Secara rinci penelitian ini untuk memperoleh jawaban terhadap pertanyaan-pertanyaan yang terkait implementasi bentuk layanan bimbingan dan konseling pada anak kelompok B1 yaitu layanan pengumpulan data, layanan informasi, layanan penempatan, layanan konseling. Penelitian ini dilaksanakan mulai bulan September 2017 sampai dengan minggu ke tiga bulan Januari 2018 di lembaga TK Kelurahan Bulusan Kecamatan Kalipuro Kabupaten Banyuwangi. Pengumpulan data menggunakan observasi, wawancara dan dokumentasi, analisis data menggunakan metode triangulasi data. Kesimpulan dalam penelitian ini adalah sudah cukup baik dalam implementasi bentuk layanan bimbingan dan konseling pada anak kelompok B1 dengan adanya kerjasama antara pihak sekolah dengan psikolog dan wali murid kelompok B1. Hal ini didapat dari adanya perencaan kegiatan hingga tahap evaluasi dan tindak lanjut dalam implementasi bentuk layanan bimbingan dan konseling pada anak kelompok B1 TK Islam Terpadu Permata Mandiri Billah 3 Banyuwangi tahun ajaran 2017/2018
\end{abstract}

Kata kunci: Implementasi bentuk layanan bimbingan dan konseling

\section{Abstract}

The purpose of this study is to describe the implementation of guidance and counseling services for children aged 5-6 TK Islam Unified Permata Mandiri Billah 3 Banyuwangi academic year 2017/2018. In detail this study to obtain answers to the questions related to the implementation of the form of guidance and counseling services in children groupB1 namely data collection services, information services, placement services, counseling service. This research was conducted from September 2017 until the third week of January 2018 in TK Islam Terpadu Permata Mandiri Billah 3 Banyuwangi. Data collection using observation, interview and documentation. Data analysis using data triangulation method. The conclusion in this research is good enough in the implementation of guidance and counseling service form for B1 group children with the cooperation between school with psychologist and guardian of group B1. This is derived from the planning of activities up to the stage of evaluation and follow-up in the implementation of the form of guidance and counseling services for children of B1 TK Islam Terpadu Permata Mandiri Billah 3 Banyuwangi academic year 2017/2018

Keywords : implementation of guidance and counseling services

\section{Pendahuluan}

Menurut Sujiono, anak usia dini merupakan individu yang hadir dengan memiliki potensi yang harus di kembangkan dalam dirinya [1]. Anak usia dini berada pada rentangan usia lahir sampai dengan usia enam tahun, dan berada dalam periode keemasan (golden age). Menurut Syaodih perlunya penerapan layanan bimbingan dan konseling pada anak usia dini untuk dapat mengembangkan potensi yang dimiliki oleh anak, perlu kiranya para orang tua dan guru memahami karakteristik perkembangan anak usia dini terlebih dahulu [2]. Setelah memahami karakteristik perkembangan anak selanjutnya menentukan pendekatan dalam bimbingan perkembangan anak usia dini.
Esensi pendidikan anak usia dini itu dalam memberikan kesempatan kepada anak agar mampu bersosialisasi dan berinteraksi sosial secara nyaman.. Layanan bimbingan dan konseling bagi anak usia dini juga dilaksanakan sebagai upaya untuk membantu anak dalam mengembangkan aspek afeksi anak. Menyadari pentingnya layanan bimbingan dan konseling untuk diterapkan di lembaga pendidikan anak usia dini, menjadi salah satu alasan dilaksanakannya implementasi bentuk layanan bimbingan dan konseling di TK Islam Terpadu Permata Mandiri Billah 3 Banyuwangi. Selain itu terdapat permasalahan perilaku anak yang membutuhkan layanan bimbingan dan konseling sedari dini mungkin, seperti perasaan sedih, perasaan marah, perasaan takut, perasaan iri dan mudah tersinggung. Anak-anak masih 
mengalami kesulitan dalam mengontrol emosi yang mereka rasakan sehingga terluaplah rasa emosi tersebut tanpa terkendali dengan baik. Tidak semua lembaga pendidikan anak usia dini memberikan layanan bimbingan konseling sebagai upaya untuk mengoptimalkan kemampuan yang telah dimiliki anak usia dini dan upaya untuk mengatasi permasalahan yang dialami oleh setiap anak .

Berdasarkan uraian di atas, peneliti mengajukan penelitian deskriptif dengan pendekatan kualitatif dengan judul implementasi bentuk layanan bimbingan dan konseling pada anak kelompok B1 usia 5-6 TK Islam Terpadu Permata Mandiri Billah 3 Banyuwangi tahun ajaran 2017/2018.

\section{Metode Penelitian}

Jenis Penelitian yang dilakukan menggunakan penelitian deskriptif dengan pendekatan kualitatif. Subjek penelitian adalah psikolog, kepala sekolah, kelompok B1 TK Islam Terpadu Permata Mandiri Billah 3 Banyuwangi di Kecamatan Kalipuro Kabupaten Banyuwangi. Penelitian ini dilaksanakan pada tanggal mulai dari bulan November 2017 sampai dengan minggu ke tiga bulan Januari 2018.

Suprayogo dan Tobroni (2001:190) menyatakan bahwa penelitian kualitatif merupakan penelitian yang datanya terdiri dari deskripsi tentang fenomena (situasi, kegiatan, peristiwa) baik berupa kata-kata, angka maupun yang hanya bisa dirasakan [3]. Data penelitian kualitatif lebih banyak dikumpulkan melalui observasi dan wawancara mendalam. Menurut Suprayogo dan Tobroni (2001:133), data yang akan dikumpulkan harus tepat agar dapat menjawab rumusan masalah atau membuktikan hipotesis yang ditetapkan [4]. Sumber data berupa manusia dalam penelitian kualitatif disebut informan. Sebagai sumber informasi (key informan), informan memiliki kedudukan penting dan harus diperlakukan sebagai subjek yang memiliki kepribadian, harga diri, posisi, kemampuan dan peranan sebagaimana adanya. Tidak semua informan memiliki kedudukan yang sama, ada informan kunci dan informan pelengkap. Penelitian yang dilakukan di TK Islam Terpadu Permata Mandiri Billah 3 Banyuwangi menggunakan psikolog, kepala sekolah dan guru kelas yang melakukan tugas konseling sebagai informan kunci. Sedangkan informan pendukung yaitu orangtua wali murid yang anaknya mendapatkan layanan bimbingan dan konseling

Metode perolehan data adalah cara atau metode yang digunakan oleh peneliti untuk mengumpulkan data yang dibutuhkan dalam kegiatan penelitian. Metode perolehan data yang digunakan dalam penelitian ini yaitu observasi, wawancara dan dokumentasi. H.B. Sutopo [4] mengemukakan bahwa teknik observasi digunakan untuk menggali data dari sumber data yang berupa peristiwa, tempat, lokasi dan benda serta rekaman gambar.

Wawancara adalah percakapan langsung dan tatap muka (face to face) dengan maksud tertentu. Percakapan itu dilakukan oleh dua pihak, yaitu pewawancara (interviewer) yang mengajukan pertanyaan dan yang diwawancarai (interviewee) yang memberikan jawaban atas pertanyaan itu [4].

Metode dokumentasi adalahan catatan peristiwa yang sudah berlalu, bisa berbentuk tulisan, gambar, atau karya- karya dari seseorang [5]. Adapun data yang dapat diperoleh dari metode dokumentasi yaitu profil sekolah TK Islam Terpadu Permata Mandiri Billah 3 Banyuwangi, profil guru, profil psikolog, anak kelompok B yang mendapatkan layanan bimbingan dan konseling, foto proses kegiatan dan data-data yang berhubungan dengan penelitian.

Menurut Suprayogo dan Tobroni (2001:191) menyatakan bahwa analisis data adalah rangkaian kegiatan penelaahan, pengelompokkan, sistematisasi, penafsiran dan verifikasi data agar memiliki nilai sosial, akademis dan ilmiah [3]. Menurut Patton (dalam Suprayogo dan Tobroni, 2001:173) menyatakan bahwa metode triangulasi paling umum dipakai dalam uji validasi dalam penelitian kualitatif [3]. Menurut Miles dan Huberman (dalam Suprayogo dan Tobroni, 2001:192) dalam penelitian ini menggunakan analisis interaktif terdiri atas tiga alur kegiatan yang terjadi secara bersamaan, yaitu: reduksi data, penyajian data, dan penarikan kesimpulan atau verifikasi [3].

\section{Hasil dan Pembahasan}

Penelitian ini dilaksanakan mulai dari bulan November 2017 sampai dengan minggu ke tiga bulan Januari 2018 di TK Islam Terpadu Permata Mandiri Billah 3 Banyuwangi Kelurahan Bulusan Kecamatan Kalipuro Kabupaten Banyuwangi. Lembaga Pendidikan Anak Usia Dini ini berdiri dibawah naungan yayasan.

Hasil temuan-temuan selama penelitian adalah sebagai

berikut:

dengan kepala sekolah dan guru kelompok B1 TK Islam Terpadu Permata Mandiri Billah 3 Banyuwangi, didapatkan informasi bahwa telah terlaksana empat implementasi bentuk layanan bimbingan dan konseling di TK Islam Terpadu Permata Mandiri Billah 3 Banyuwangi tahun ajaran 2017/2018. Diantaranya yaitu layanan pengumpulan data, layanan informasi, layanan penempatan, layanan konseling.

2. Pelaksanaan bentuk layanan bimbingan dan konseling pada kelompok B1 di sekolah mulai dari dalam pengumpulan data, pada awal tahun ajaran baru pihak sekolah mengadakan interview dengan wali murid. Dimana kepala sekolah dan wakil melakukan interview untuk mengetahui perkembangan anak mulai dari dalam kandungan sampai tiap tahapan usianya, kebiasaankebiasaan di rumah, dan makanan yang diberikan oleh orangtua. Pihak sekolah melakukan tes psikologi kepada anak, hal ini untuk mengetahui psikologi anak apakah dia memiliki permasalahan awal dalam tahapan perkembangan atau tidak.

3. Tempat dilaksanakannya bentuk layanan bimbingan dan konseling yang diberikan oleh guru mulai dilaksanakan itu pada saat awal masuk sekolah tahun ajaran baru, pada saat proses pembelajaran, pada saat anak bermain, saat pertemuan orangtua dengan sekolah, kegiatan parenting dan konseling untuk orangtua pada saat home visit di rumah anak.

4. Pertimbangan sekolah menjelaskan bahwa pentingnya pengimplementasian bentuk layanan bimbingan dan konseling pada anak kelompok B1 usia 5-6 TK Islam Terpadu Permata Mandiri Billah 3 Banyuwangi tahun 
ajaran 2017/2018 adalah agar anak dapat mengenal diri, kemampuan, sifat, kebiasaan, kesenangan serta dapat mengembangkan potensi yang dimilikinya.

5. Hal-hal pendukung kegiatan implementasi bentuk layanan bimbingan dan konseling yaitu adanya kerjasama yang cukup baik dalam pelaksanaan bentuk layanan bimbingan dan konseling pada anak, hal ini dibuktikan dengan terjalinnya kerjasama antara pihak sekolah dengan psikolog untuk melakukan tes psikologi dan observasi kepada anak dengan tujuan untuk mendeteksi dan memberikan solusi atas kendala atau permasalahan tersebut.

6. Hal-hal yang menghambat kegiatan implementasian bentuk layanan bimbingan dan konseling di TK Islam Terpadu Permata Mandiri Billah 3 Banyuwangi yaitu masih belum ada tenaga psikolog tetap yang bekerja sebagai guru di sekolah tersebut serta keterbatasan jumlah guru untuk dapat menerapkan bentuk layanan bimbingan dan konseling pada setiap anak. layanan bimbingan dan konseling dengan media pembelajaran yang lebih inovatif.

3. Bagi program studi, hasil penelitian ini dapat dijadikan dokumentasi skripsi dalam penelitian deskriptif kualitatif dan sebagai bahan referensi penelitian yang relevan selanjutnya.

\section{Daftar Pustaka}

[1] Sujiono, Y. N. 2009. Konsep Dasar Pendidikan Anak Usia Dini. Jakarta: Indeks.

[2] Masyhud, Sulthon. 2014. Metode Penelitian Pendidikan. Jember: Lembaga Pengembangan Manajemen dan Profesi Kependidikan (LPMPK)

[3] Suprayogo, I. dan Tobroni. 2001. Metodologi Penelitian SosialAgama. Bandung: Remaja Rosdakarya.

[4] Prayitno \& E. Amti. 2004. Dasar-Dasar Bimbingan dan Konseling. Jakarta: Rineka Cipta.

[5] Sutirna. 2013. Bimbingan dan Konseling (Pendidikan Formal, Nonformal dan Informal). Yogyakarta: Andi Offset.

\section{Kesimpulan dan Saran}

\section{Kesimpulan}

Berdasarkan analisis data, maka dapat disimpulkan implementasi bentuk layanan bimbingan dan konseling telah berjalan dengan baik dengan adanya kerjasama dari berbagai pihak. Pihak sekolah dengan psikolog serta wali murid TK Islam Terpadu Permata Mandiri Billah 3 Banyuwangi. Terdapat empat bentuk layanan bimbingan dan konseling yang telah di terapkan di TK Islam Terpadu Permata Mandiri Billah 3 Banyuwangi dan berjalan dengan baik. Mulai dari tahap perencanaan sampai dengan tahap evaluasi dan tindak lanjut Implementasi Bentuk Layanan Bimbingan dan Konseling pada Anak Kelompok B1 Usia 5-6 TK Islam Terpadu Permata Mandiri Billah 3 Banyuwangi Tahun Ajaran 2017/2018 Kelurahan Bulusan Kecamatan Kalipuro Kabupaten Banyuwangi.

Pelaksanaan bentuk layanan bimbingan dan konseling pada anak kelompok B1 usia 5-6 TK Islam Terpadu Permata Mandiri Billah 3 Banyuwangi tahun ajaran 2017/2018 dilakukan di berbagai tempat dan keadaan seperti pada saat proses pembelajaran, pada saat anak bermain, saat pertemuan orangtua dengan sekolah, kegiatan parenting dan konseling untuk orangtua pada saat home visit di rumah anak.

\section{Saran}

Berdasarkan hasil penelitian tersebut, maka dapat diberikan saran-saran sebagai berikut:

1. Bagi Guru, dalam kegiatan pembelajaran hendaknya menggunakan model pembelajaran yang disertai teknik, metode, media yang sudah dipersipkan dengan baik dalam penerapan bentuk layanan bimbingan dan konseling.

2. Bagi peneliti lain, hasil penelitian implementasi bentuk layanan bimbingan dan konseling pada anak kelompok B1 usia 5-6 TK Islam Terpadu Permata Mandiri Billah 3 Banyuwangi tahun ajaran 2017/2018 ini diharapkan dapat dijadikan landasan untuk penelitian lebih lanjut mencoba dan mengkombinasikan implementasi bentuk 